\title{
Problematic pit: closure liability to operational opportunity
}

\author{
CL Latham Rio Tinto, Australia
}

C Lazo-Skold Rio Tinto, Australia

\begin{abstract}
This paper presents a case study of an innovative solution to a problematic mined-out pit in the Pilbara region of Western Australia. The pit presented significant closure challenges, being deep, below water table and with approximately $17 \%$ of potentially acid forming (PAF) lithology on the final pit shell. Numerous closure strategy options have been under consideration; however, a new strategy of backfilling the pit with process tailings has been identified. Modelling predicts that the tailings will cover a large proportion of the PAF lithology leading to improved water quality conditions and will also fill the pit to a level that prevents the formation of a permanent pit lake. Furthermore, the initiative will negate the need for construction of further ex-pit tailings capacity and prevent the associated environmental impacts. Significant cost savings in tailings facility construction, tailings deposition and closure implementation are anticipated. Regulatory approval of the in-pit tailings facility is required, and consultation has commenced.
\end{abstract}

Keywords: pit lake, tailings, potentially acid forming waste, acid mine drainage, closure

\section{Introduction}

The pit is located at a large operational iron ore mine in the Pilbara region of Western Australia (Figure 1), that has been operating continuously since 1966. Iron ore is mined from open cut pits utilising conventional drill-and-blast, load and haul mining methods. Waste rock is placed in ex-pit waste dumps, in-pit backfill or used for construction purposes. The ore is crushed, screened and beneficiated the mine site, processing waste fines are placed in designated tailings storage facilities.

A significant geochemical risk in Pilbara iron orebodies is associated with sulphides, such as pyrite $\left(\mathrm{FeS}_{2}\right)$, which can form sulphuric acid $\left(\mathrm{H}_{2} \mathrm{SO}_{4}\right)$ when exposed to oxygen and water. Sulphide oxidation can lead to the generation of acid and metalliferous drainage (AMD) with sulphate concentrations typically ranging between 500 to $10,000 \mathrm{mg} / \mathrm{L}$ (Hill 1968) and metal concentrations often exceeding the Australian and New Zealand Guidelines for Fresh and Marine Water Quality (Australian and New Zealand Environment and Conservation Council \& Agriculture and Resource Management Council of Australia and New Zealand [ANZECC \& ARMCANZ] 2000). Mount McRae Shale (MCS) is the geological unit most commonly associated with AMD at iron ore mines in the Pilbara. MCS is exposed and extracted during the process of mining at the site and has been actively managed via a stringent operational management plan since at least 1999, these management strategies are summarised in Green (2009). Identification, planning and management of potentially acid forming (PAF) mineral wastes at Rio Tinto's Pilbara operations was recently recognised with a corporate best practice award by the International Network for Acid Prevention at the 2018 International Conference on Acid Rock Drainage.

Nonetheless, MCS remains exposed to oxygen and water in pit shells resulting in localised AMD runoff. In general, AMD contains sulphuric acid and high concentrations of metals. Therefore, it has the potential to present a major risk to aquatic life, riparian vegetation and water resources (Department of Industry, Tourism and Resources 2016). The presence of localised AMD at the mine site has been reported to the appropriate Western Australian regulator via the Contaminated Sites Act 2003 (WA), and an acid water treatment plant (AWTP) is present to treat affected water.

The pit in question, a deep, below water table pit with extensive MCS exposures is scheduled to be mined-out in 2019. Without active management it is predicted that an evaporative, terminal sink pit lake 
will develop. A pit lake forms a terminal sink where evaporation exceeds the rate of groundwater inflow, hence, the void acts as a groundwater sink (Johnson \& Wright 2003). Poor quality water will be confined to the local pit area due to the low hydraulic conductivity of the surrounding geology forming an aquitard between the orebody and other local aquifers. A terminal sink pit lake forms the default closure strategy for the pit.

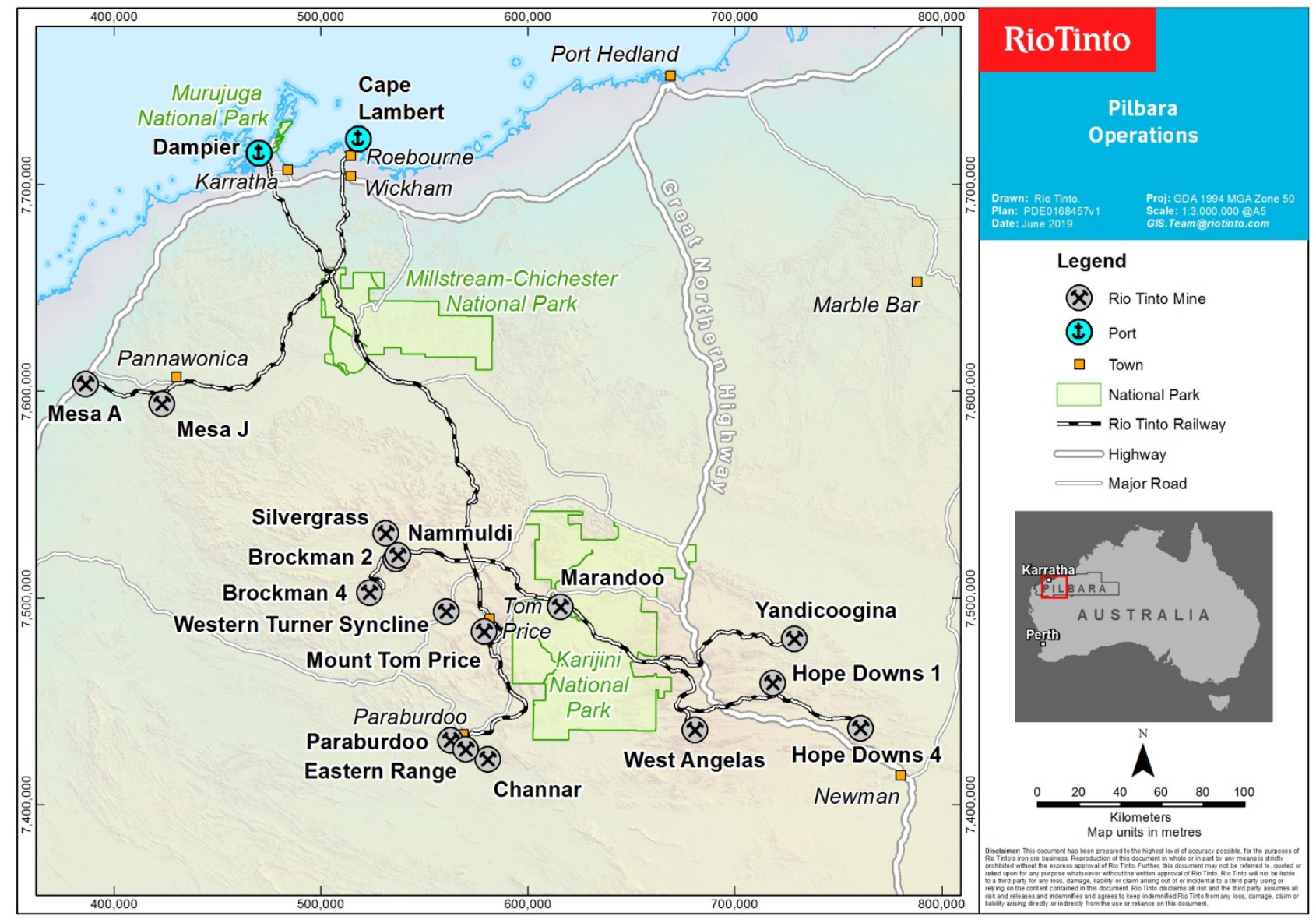

\section{Figure 1 Site location}

A closure risk assessment undertaken in 2013 identified the opportunity to deposit tailings into the exhausted pit, with the improved position based on tailings covering the MCS on the pit shell, leading to improved water quality within the pit. Covering the MCS would limit oxygen ingress and contact with surface water runoff, and therefore limit the production of AMD. This strategy would result in significant cost savings by eliminating both the need to construct ex-pit tailings facilities and implement substantial closure management strategies. A multi-disciplinary technical team was formed to explore the opportunity, and the modelling described in this paper was undertaken to guide order of magnitude and pre-feasibility studies.

\section{$2 \quad$ Background setting}

\subsection{Climate}

The climate in the mine area can be characterised as arid-tropical with two distinct seasons, hot wet summers and cooler dry winters. Mean daily maximum temperatures range from $23^{\circ} \mathrm{C}$ in winter to $38^{\circ} \mathrm{C}$ in summer. Precipitation is driven by summer cyclonic activity, with the months of August, September and October recording the lowest average rainfall, and January, February and March the highest average rainfall. Annual rainfall averages $399 \mathrm{~mm}$ and is highly variable. The average annual pan evaporation rate is $3,200-3,600 \mathrm{~mm}$. Evaporation rates in the region greatly exceed rainfall, which is typical for similar climate conditions around Australia. 


\subsection{Geology}

The regional geology is characterised by the Archaean granitic and altered basic igneous rocks that underlie the Proterozoic sediments of the Hamersley Basin. The mid-sequence of which is the Hamersley Group which contains units of banded iron formations (BIF) that characterise the Pilbara.

Mineralisation occurs in the Dales Gorge (DG) Member of the Brockman Iron Formation, which occurs within the lower sequences of the Hamersley Group. Immediately underlying the DG unit is the MCS formation, of which pyritic black shale is the dominant lithology. The uppermost section of the MCS formation, the Colonial Chert Member consists of thin BIF units with interbedded shale and is known locally as the Footwall Zone (FWZ) (Thorne et al. 2004). Immediately underlying the MCS is the Mount Sylvia (MTS) Formation, the uppermost eight metres of which is referred to as Bruno's Band. The Wittenoom Formation underlies the MTS, and forms the main regional aquifer.

It is necessary to mine out MCS as overburden waste in order to access the DG ore. Measures to manage MCS exposures have been in place since at least 1999 with their focus being minimisation and prevention of $A M D$, rather than control or treatment.

\subsection{Mount McRae Shale geochemical characteristics}

At Rio Tinto's Pilbara operations, MCS is classified into three types based on pyrite content: oxidised MCS, cold black MCS and hot black MCS. Both the cold and hot black MCS units are managed as PAF during operations with the hot black shale having higher total sulphur content (generally $>0.3 \%$ ). Un-oxidised, reactive black shale encountered below the pre-mining water table poses the most significant risk of selfheating and generating AMD. Oxidised MCS is considered inert.

Geochemical testing undertaken at the mine site indicates that sulphides in MCS are highly reactive with little lag period before the onset of acid conditions. Following acidification, low pH leachates may potentially have elevated concentrations of aluminium (Al), arsenic (As), cadmium (Cd), cobalt (Co), copper $(\mathrm{Cu})$, iron $(\mathrm{Fe})$, manganese $(\mathrm{Mn})$, nickel $(\mathrm{Ni})$, zinc $(\mathrm{Zn})$ and sulphate. Sulphide oxidation can also potentially lead to the generation of high salinity (with sulphate concentrations typically ranging between 500 to $10,000 \mathrm{mg} / \mathrm{L})$.

\subsection{Tailings characteristics}

The iron ore beneficiation process involves crushing, wet screening and separation of fines in cyclones and spirals. The separated fines are then thickened and pumped to tailings storage facilities. The tailings are classified as clays with some silt, with some plasticity (Plasticity Index $=12 \%$ ), the Emerson Class number of the tailings samples was six (non-dispersive). Column settling testing showed that the tailings settle quickly, and had completely settled in approximately six days.

Geochemical characterisation work undertaken on tailings from the site to date classified the material

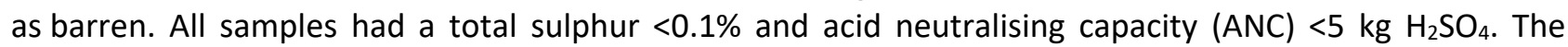
tailings are non-acid generating (neutralisation potential ratio $(\mathrm{NPR})=3.3$, net acid generation $\mathrm{pH}=7.8$ ) and consist primarily of goethite/hematite, kaolinite and quartz. The tailings decant water is monitored regularly and shows that the decant water is circum-neutral. The only process chemical added is a flocculant for thickening. The risk of acidic tails is low and no management for AMD is required other than risk associated with saline water generation that is typical of tailings dam operation.

\subsection{Hydrogeology}

The main aquifers in the pit area include the DG Member Orebody Aquifer, Bruno's Band Chert Aquifer and the Wittenoom Dolomite Aquifer. Groundwater occurs in fractured rock aquifers (sedimentary and igneous) where secondary porosity has developed in fractured or weathered zones or along bedding plane partings or joints. The basement rocks are tight outside the zone of secondary porosity and contain little or no groundwater. Recharge is episodic and affected by direct infiltration of rainfall and leakage from surface 
flows. In the pit area, groundwater is present in mineralised and permeable units of the DG Member of the Brockman Iron Formation. Often the units are completely surrounded by lower permeability un-mineralised BIF and/or McRae Shale units in broad synclinal or fault controlled structures (Figure 2). This structural control on the water movement (or compartmentalisation) results in local, rapid changes in groundwater levels, which adds complexity to groundwater dewatering strategies and predictions of groundwater recovery. Impermeable dolerite dykes and fault gouge associated with the Southern Batter Fault are likely to aid groundwater compartmentalisation.

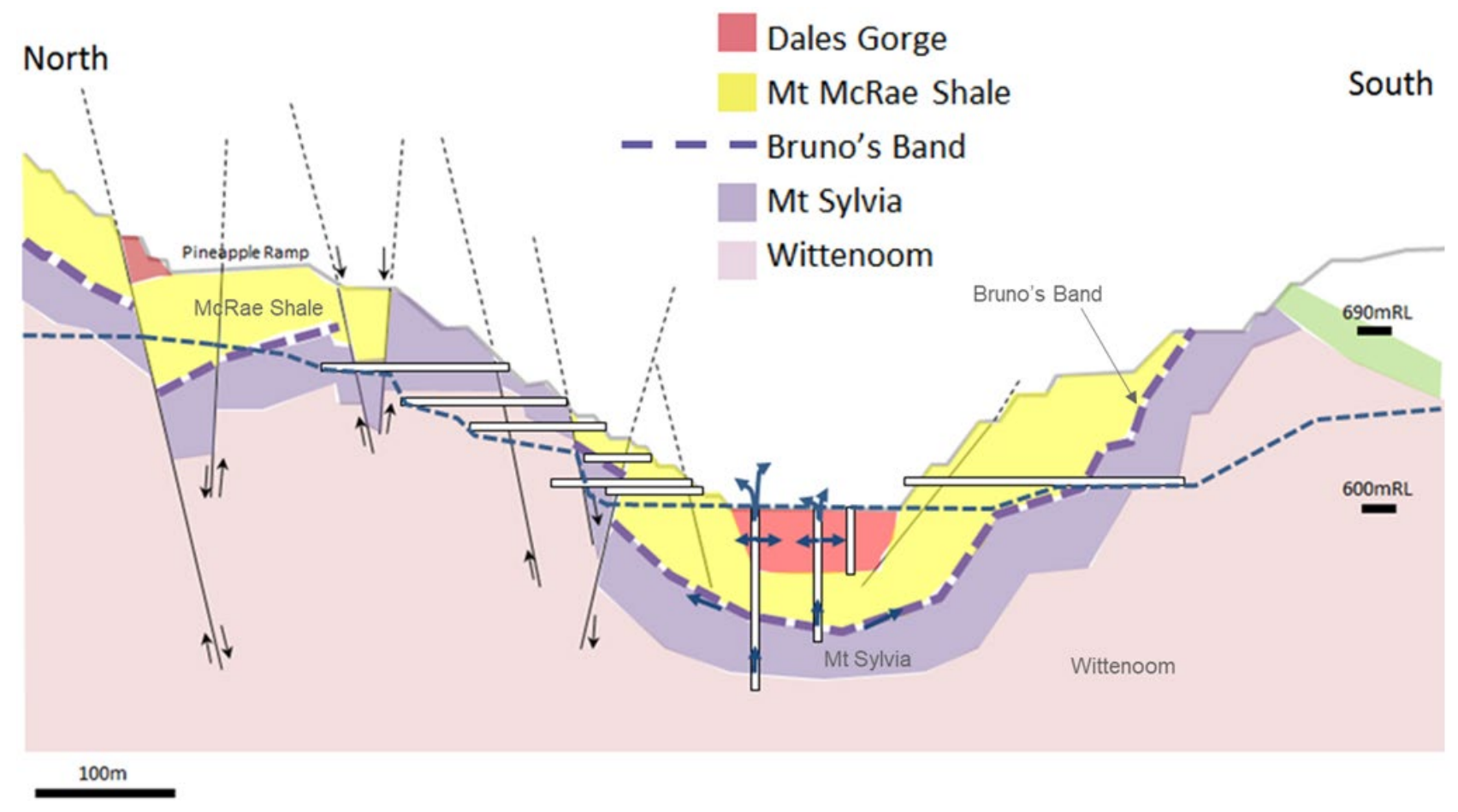

Figure 2 Conceptual hydrogeological model cross-section of the pit area

The pre-mining water table level in the orebody aquifer is estimated to have ranged from 680 to $660 \mathrm{~m} \mathrm{RL}$, dipping to the south. Large-scale dewatering commenced at the mine site in 1997; altering the pre-mining groundwater flow regime in some areas. Mining should effectively leave the area stripped of most of the highly permeable units (the orebody).

The Bruno's Band Aquifer is hosted by the chert band within the upper unit of the MTS Formation. The chert band shows high permeability where faulted and folded. The Wittenoom Dolomite Aquifer forms the main regional aquifer system and it is typically hosted within the dolomitic Paraburdoo Member of the Wittenoom Formation. Some dewatering bores have been drilled through the low permeability BIF and MCS into the Bruno's Band and Wittenoom Aquifers. This has resulted in artesian flows from these boreholes.

Although dewatering has impacted the local aquifer systems, it is predicted the regional groundwater system will remain intact post-closure. The groundwater in the deposit is compartmentalised and disconnected from regional aquifers. The degree and rate of recovery of these systems at closure is difficult to predict, particularly due to the sporadic nature of intense rainfall events. A conceptual deposit based groundwater model has been developed to predict post-closure recovery levels for the water table. It is predicted the water table will recover within the range 620 to $690 \mathrm{~m} \mathrm{RL}$.

Groundwater in the mine area can be generally classified as magnesium-chloride-sulphate $\left(\mathrm{Mg}-\mathrm{Cl}-\mathrm{SO}_{4}\right)$ type groundwater, with a tendency to change to chloride-sulphate-bicarbonate $\left(\mathrm{Cl}_{-}-\mathrm{SO}_{4}-\mathrm{HCO}_{3}\right)$ type water depending on geological substrate influence. Groundwater within the DG Member tends to exhibit lower anion concentrations, with higher levels of chloride. The FWZ, however, tends to produce groundwater with low concentrations of bicarbonate and carbonate. This is likely due to the progression into the 
sulphate rich MCS, of which the FWZ is a sub-unit. Groundwater flow-through the Wittenoom Formation characteristically has higher concentrations of calcium with much lower sulphate concentrations.

\subsection{Hydrology}

The pit is sited on the divide between three major catchments and there are no named rivers or creeks within the mine area. As for most parts of the Pilbara, minor watercourses in the mine catchment are naturally dry; flows are ephemeral, occurring only after significant and intense rainfall events. No naturally occurring permanent surface water bodies are located in proximity to the mining area. Mining has significantly altered the local surface water catchments and the pit is now internally draining.

\subsection{Sensitive receptors}

The mine area has been surveyed extensively for potential receptors. No conservation significant habitats have been identified that are analogous to any known threatened ecological community, as an environmentally sensitive area or as a priority ecological community. No significant wetlands or surface water bodies, such as permanent pools or waterholes, have been identified in the vicinity of the mine. There are no named creeks or rivers located within the operating area, and the mine does not encompass or cross any significant floodplains. No archaeological or ethnographic sites are expected to be impacted by closure of the pit.

A drinking water reserve underlies the pit area; with the drinking water production bores located some $80 \mathrm{~km}$ away. A hydrogeological study determined that the pit and the drinking water borefield are not hydraulically connected. As the local catchment area has been significantly altered by mining, and the pit area is now internally draining, it is considered unlikely that surface water flows could affect water quality within the drinking water borefield.

\section{$2.8 \quad$ Pit context}

Mining of the pit commenced in the 1970s, therefore legacies of poor historical environmental management practices are present, which will be managed to meet current stakeholder expectations where it is reasonable to do so. The pit crest ranges from $1,040 \mathrm{~m} \mathrm{RL}$ on the highest side (northern) to $765 \mathrm{~m} \mathrm{RL}$ on the lowest side (southern). Mining is scheduled to be completed this year (2019) with a final pit floor level of $570 \mathrm{~m} \mathrm{RL}$; therefore, the pit floor will range from $470 \mathrm{~m}$ to $195 \mathrm{~m}$ below the surrounding natural ground level. The pre-mining natural groundwater level is estimated to have ranged from the $680 \mathrm{~m} \mathrm{RL}$ on the northern side of the pit, to $660 \mathrm{~m} \mathrm{RL}$ on the southern side. On the completion of mining the pit floor will extend 110 to $90 \mathrm{~m}$ below the pre-mining groundwater level.

It is estimated that on the completion of mining the pit will have $369,185 \mathrm{~m}^{2}$ of MCS exposed on the pit wall, or $17.2 \%$ of the pit shell (14.2\% of cold MCS and $3.0 \%$ of hot MCS) (Figure 3 ). Exposed PAF material in pit walls has the potential to generate acidic runoff if it comes into contact with incident rainfall, or surface water runoff. Currently, runoff collects in the base of the pit; intermittent ponded water on the pit floor has been monitored since 2004, the $\mathrm{pH}$ of which has been varied, ranging from acidic to circum-neutral.

During active dewatering AMD has been evident in groundwater from a number of bores screened in the DG or MCS units in the vicinity of the pit. The conceptualisation of the hydrogeology at the pit indicates that any impact to groundwater is restricted to the Brockman Orebody Aquifer in the DG Member and the MCS. Groundwater samples from dewatering bores screened within the underlying MTS and Wittenoom Formation do not show $\mathrm{pH}$ values or sulphate concentrations that are indicative of AMD impact to groundwater. This supports the understanding that there is limited connection between these aquifers and that groundwater will be contained to the local pit area. A site AWTP was constructed in 2008 for the treatment of $A M D$, where required, water is neutralised through the addition of lime slurry and then recycled for operational uses. 


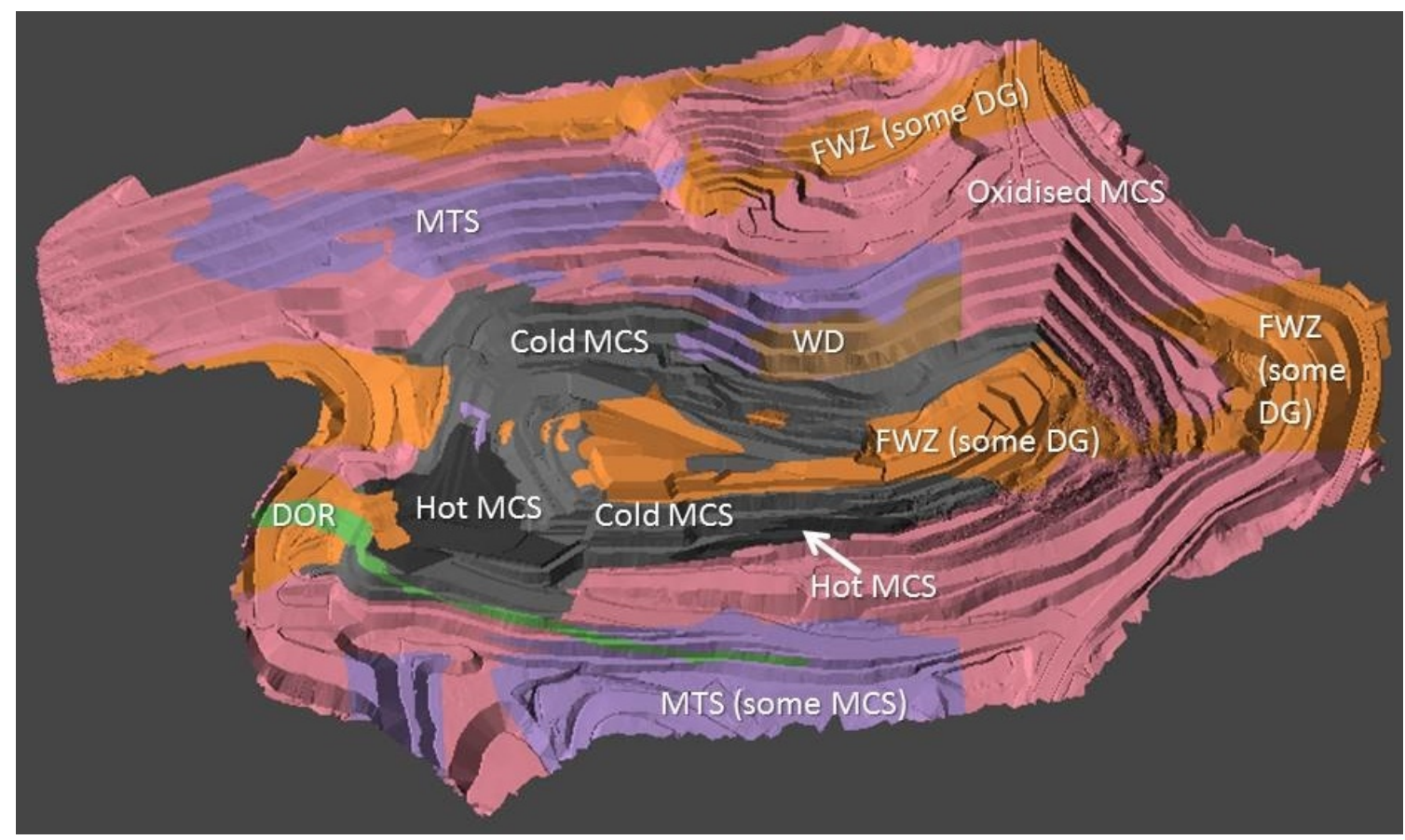

Figure 3 Predicted pit shell lithology on the completion of mining

\subsection{Proposed closure strategy}

On the completion of mining it is expected that a permanent pit lake sustained by groundwater and surface water (rainfall and runoff) would form within the pit if left with no backfill. The groundwater level is predicted to recover to between the 620 to $690 \mathrm{~m} \mathrm{RL}$ post-closure, with the final pit floor at $570 \mathrm{~m} \mathrm{RL}$, and therefore a 50 to $120 \mathrm{~m}$ deep pit lake would form. The conceptual hydrogeological model indicates the lake will be a terminal sink, with no net groundwater outflow. Due to the exposed MCS in the pit wall it is predicted that the pit lake water quality would be poor. Pit lake sinks are subject to evaporation processes and as a result, salts and metals will slowly concentrate in the lake water. Groundwater sinks are not expected to have a degrading effect on regional groundwater quality. Conceptual modelling suggests that groundwater will flow towards the pit, containing any poor quality water within the immediate area. Leaving a pit lake has been suggested as the only practical option for the very large pits, such as Mount Whaleback and Tom Price in the Pilbara and the Super Pit at Kalgoorlie, which are not directly linked to significant regional water resources and are too large to backfill (Johnson \& Wright 2003).

Alternative closure strategies to improve pit lake water quality were explored, such as using shotcrete to cover MCS exposures, with none proving viable. Depositing process tailings into the pit to cover MCS exposures and therefore limit AMD production, has been identified as an opportunity to improve water quality within the pit. A multi-disciplinary technical team was formed to explore the opportunity, and the modelling described below was commissioned.

\section{$3 \quad$ Modelling}

A water and solids balance calculation was developed to assist with the investigation of water quality impacts from tailings deposition into the pit. Outputs from the water and solids balance model were then used as inputs to the geochemical water quality model.

\subsection{Water and solids balance model}

As mentioned before the pit is surrounded by low permeability units. During mining the only observed groundwater inflow to the pit occurred predominantly via horizontal and vertical depressurisation bores advanced in deeper aquifers. Reversal of flows in these bores and potential seepage out of the pit post- 
closure have been assessed as minor and were therefore not considered during the modelling efforts. Thus, the pit was modelled as a simple 'bucket' where the only outputs from the system included evaporation and decanting. A conceptual model for the pit is depicted on Figure 4. The water and solids balance model included the following components: incident rainfall, evaporation, pit wall runoff, catchment runoff, groundwater inflow, tailings inflow, tailings solids consolidation, and decant outflow. The water and solids balance model was developed using the GoldSim @ software (Kossik \& Miller 2017).

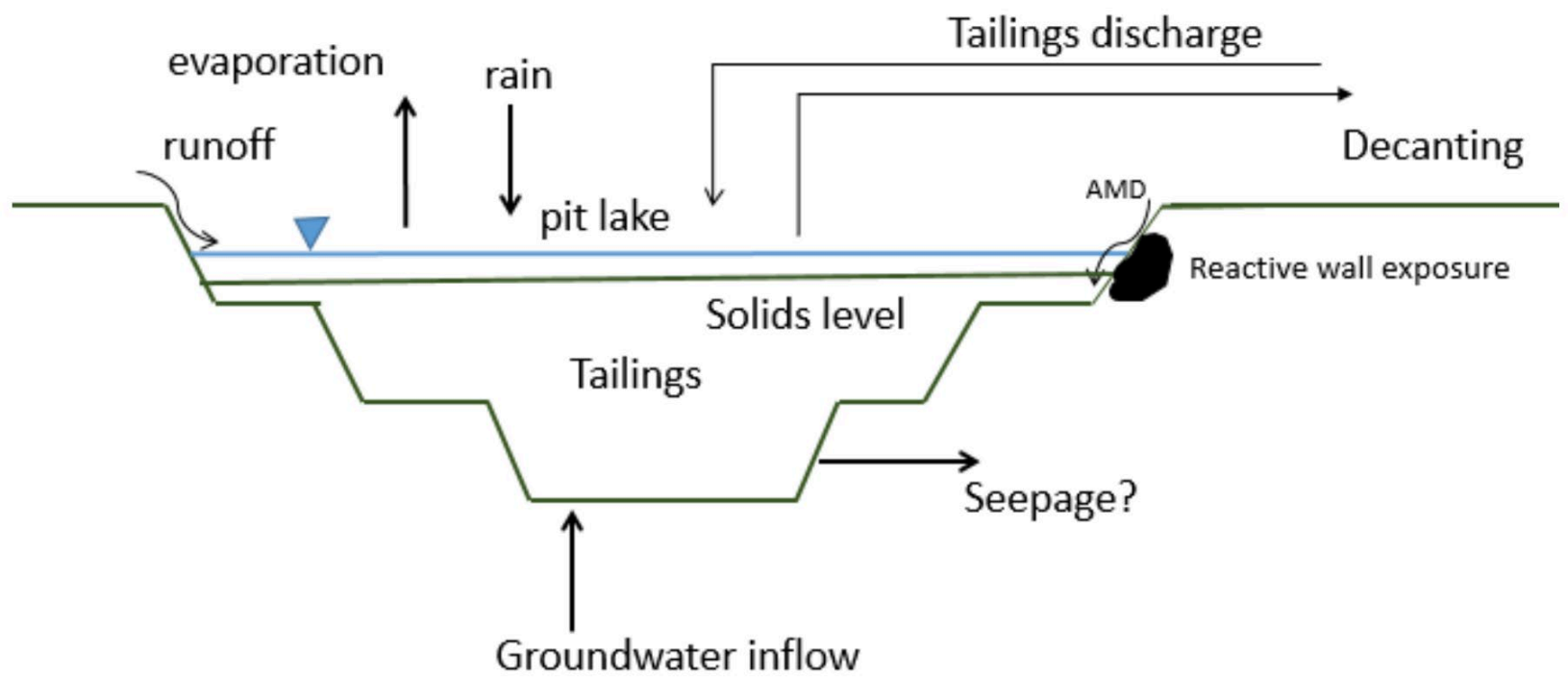

Figure $4 \quad$ Conceptual water and solids pit model

\subsubsection{Rainfall}

Daily rainfall was generated by a stochastic daily rainfall model, which simulated a Markov process that randomly switches between a wet state and a dry state to generate daily rainfall events. When in the wet state a Weibull probability distribution determines the magnitude of daily rainfall intensity and a prescribed monthly probability of rainfall determines the occurrence of rainfall. When in the dry state, no rainfall occurs. In addition to parameters describing the Weibull probability distribution, the generated daily rainfall sequence is controlled by three model parameters; namely, average storm duration, average storm depth, and probability of a storm occurring on any given day.

Values for these three model parameters were derived from a historic daily rainfall record (whole years 1999 to 2014, inclusive) sourced from the site based weather station. Values describing the Weibull probability distribution were calibrated to the following statistics of simulated and recorded datasets:

- mean annual total rainfall.

- $1 \%$ annual total rainfall (to ensure the very dry years were reproduced).

- $99 \%$ peak daily rainfall (to ensure the extreme high intensity storms were reproduced).

Calibration was achieved using GoldSim's optimisation feature by developing an objective function that is the sum of the differences between the Markov model and statistics of historic data in the above three statistical parameters.

\subsubsection{Evaporation}

Open-water evaporation is represented in the GoldSim model by interpolation of a series of Class A pan records throughout the Western Australia region. These values have been compared to mean monthly evaporation calculated using the Penman combination equation and field data recorded by an onsite weather station, as described elsewhere (Luke et al. 1987; McMahon et al. 2013; Vardavas \& Fountoulakis 1996). A daily record of Penman open-water evaporation was calculated for one complete calendar year (January 2015 to December 2015) and then compared to modelled values using pan evaporation factors 
and those obtained from the nearest known published record of evaporation at the Australian Bureau of Meteorology (BoM) Wittenoom gauge station ID 005026. The BoM Wittenoom gauge is located $75 \mathrm{~km}$ from the mine at an altitude of $463 \mathrm{~m}$ which is much lower than the mine at $742 \mathrm{~m}$ and is therefore likely to experience different climatic conditions.

Available daily recorded climate data for the mine site included:

- Average radiation was assumed to represent the combined net shortwave and longwave energy at the Earth's surface.

- Minimum, average and maximum temperature.

- Minimum, average and maximum relative humidity.

- Average wind speed.

While open-water evaporation calculated from the onsite climate record approximated a fixed monthly pan factor of 0.65 to adjust Class A pan measurements of evaporation, average annual open-water evaporation determined from the BoM Wittenoom gauge Class A pan record was much lower than estimates calculated from the onsite climate data. This may be due to differences in local climatic conditions at Wittenoom compared to the mine location. While the open-water evaporation record calculated from onsite climate data is limited to just one complete year (2015), an analysis of the record at Wittenoom suggests the evaporation total for year 2015 was representative of the long-term average. Though it is preferable to use site specific data to obtain an estimate of evaporation this is not always possible. For this reason, regional pan evaporation factors have been used in this model; however, fixed pan factor have been replaced by variable monthly pan factors based on those reported for the BoM Paraburdoo gauge station ID 007178 (located $80 \mathrm{~km}$ from the mine).

\subsubsection{Runoff}

A pit overflow level of RL $760 \mathrm{~m}$ was assumed and is the limit of the available pit void space. Surface water runoff from areas above this level comprise higher sections of pit wall, an external catchment beyond the northern pit wall and an adjacent pit catchment located to the west of the pit perimeter. The combined area of the pit void space (planar area of pit walls and floor) and external catchment was calculated to be $1.88 \mathrm{~km}^{2}$.

For simplicity surface runoff from external catchments was generated in the model as a fixed proportion (0.35) of daily rainfall, while that from pit walls is set to be equal to 0.9 of daily rainfall. A sensitivity analysis involving changes to surface runoff coefficients was carried out to assess the impact on pit lake water levels.

\subsubsection{Groundwater inflow}

The rate of groundwater seepage inflow into the pit is controlled by the relative head between the pit and the aquifer and will be controlled by the physical characteristics of the deposited tailings. Based on the potentiometric head in Bruno's Band and the orebody water level, the current vertical hydraulic gradient is in the order of 0.21 . Since mid-2012 the orebody groundwater level has been kept roughly constant via cumulative in-pit pumping at a mean rate of approximately $24 \mathrm{~L} / \mathrm{s}\left(2,070 \mathrm{~m}^{3} /\right.$ day $)$.

An estimate of groundwater seepage for future pit water elevations can be obtained by a ratio of hydraulic gradients using the recorded condition referred to above as a reference. The flow rate, $Q$, is directly proportional to the hydraulic vertical gradient assuming the surface area and hydraulic conductivity will remain constant over time (a reasonable assumption) given the orebody is wrapped around on all sides by MCS and Bruno's Band.

Thus, a simple linear relationship between groundwater seepage and pit water level has been included in the model and assumes: 
- Seepage is predominantly through horizontal and vertical depressurisation holes and bore casing screens.

- Bores are not sealed before deposition of tailings commences.

- Incoming groundwater seepage keeps the tailings slurry liquefied and its hydraulic conductivity greater than that of the confining layer.

\subsubsection{Tailings inflow}

Estimates of tailings solids and water inflow were based on long-term records of tailings production at the site. A tailings production rate of $1.5 \mathrm{Mtpa}$ was used for storage modelling. This is $15 \%$ higher than production rates recorded since 2013 and thus is conservative and allows for small increases in tailings production. The selected input data consisted of a time series of hourly values over a period of three years. The projected mean inflow rate of tailings for a period of 18 years was $390.7 \mathrm{~m}^{3} / \mathrm{h}$, comprising $45.2 \mathrm{~m}^{3} / \mathrm{h}$ of solids and $345.5 \mathrm{~m}^{3} / \mathrm{h}$ of water.

Based on the 2017 life-of-mine plan $30.65 \mathrm{Mt}$ of fine tailings will be produced between July 2019 and end of 2041. The available volume within the pit for tailings deposition and water storage is shown in Figure 5; this storage curve was calculated using the Vulcan software. The pit has approximately $35 \mathrm{Mm}^{3}$ of storage capacity between $570 \mathrm{~m} \mathrm{RL}$ and $715 \mathrm{~m} \mathrm{RL}$, which is enough to accommodate life-of-mine tailings production. The tailings rate of rise will initially be rapid with the tailings top surface rising to $590 \mathrm{~m} \mathrm{RL}$ in the first year, levelling off to reach $675 \mathrm{~m} \mathrm{RL}$ by the end of 2041.

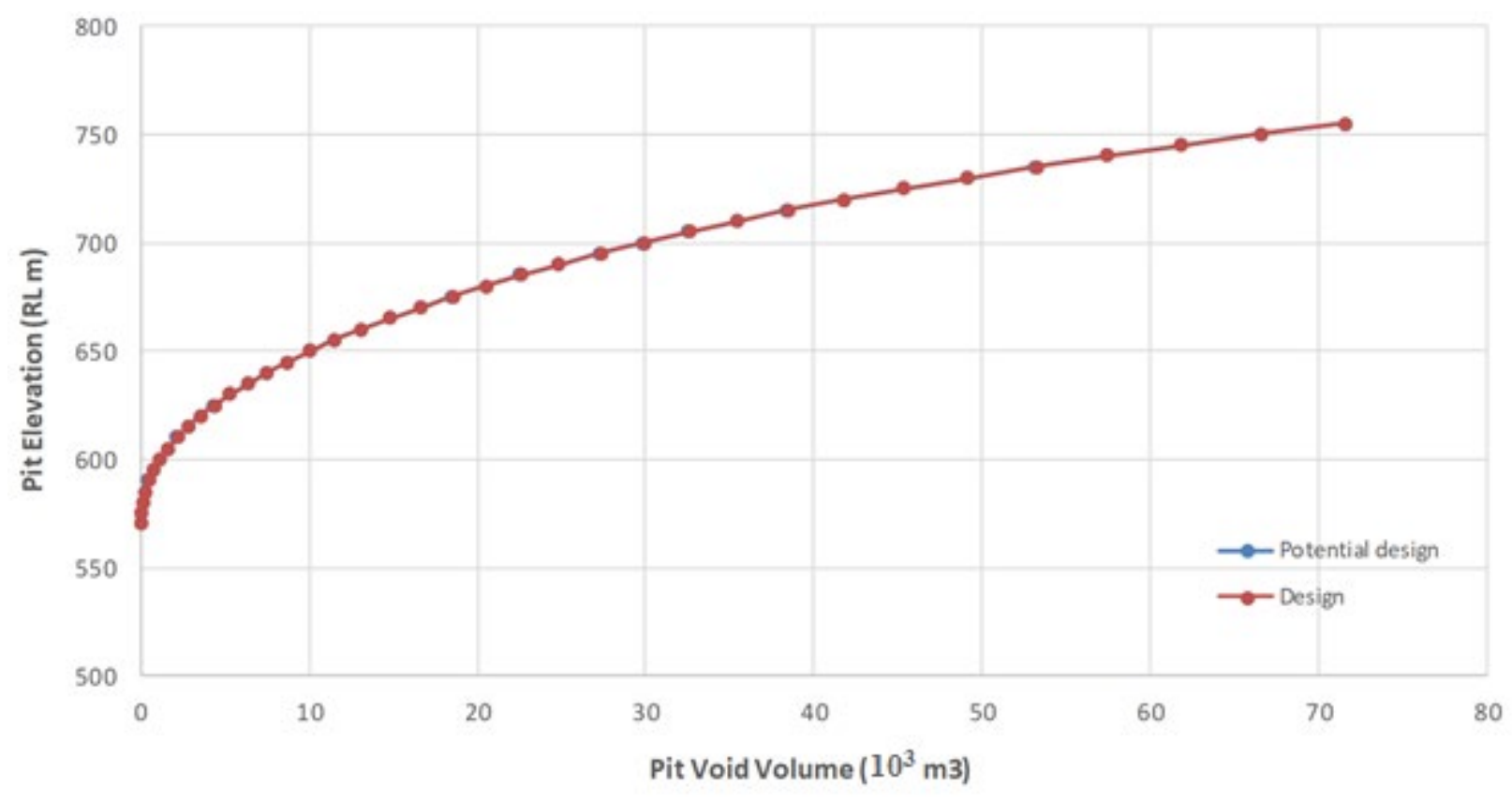

Figure 5 Pit void volume storage curve

\subsubsection{Solids consolidation modelling}

A simplified spreadsheet model was developed to model the consolidation of the tailings within the pit over time and was then incorporated into the GoldSim water and solids balance model. The consolidation estimates were based on Rowe Cell consolidation test results conducted for the project. The simplified spreadsheet model was developed primarily to allow tailings solids to be incorporated into the GoldSim modelling, and was considered appropriate for this purpose. The following assumptions were included in the spreadsheet model:

- Tailings deposition occurs for 6,500 h pa. 
- Tailings solids flow rate of $166 \mathrm{t} / \mathrm{hr}$ and water flow rate of $345.5 \mathrm{~m}^{3} / \mathrm{h}$.

- Solids specific gravity of 3.66 based on test results.

- Pit storage volume based on Vulcan model storage curve.

The consolidation calculation was initially performed by calculating the consolidation at $1 \mathrm{~m}$ water level intervals within the pit. The consolidation was calculated by interpolating the void ratio from the Rowe Cell consolidation test results based on the effective vertical stress at the base of each layer. The Rowe Cell testing was limited to a maximum stress of $640 \mathrm{kPa}$, and the corresponding void ratio at this stress was 1.089. The maximum stress of $640 \mathrm{kPa}$ corresponds to an approximate depth of tailings of approximately $42 \mathrm{~m}$, based on a stored density of tailings of $1.5 \mathrm{t} / \mathrm{m}^{3}$. Beyond the maximum stress of $640 \mathrm{kPa}$, the void ratio could not be interpolated and the void ratio of 1.089 was adopted for input into the GoldSim model at the time of the modelling. It is noted that this is a conservative estimate, and the void ratio will further reduce once the vertical stresses exceeds $640 \mathrm{kPa}$ (once tailings are deeper than approximately $42 \mathrm{~m}$ ). After the initial GoldSim modelling, a relationship between stress and void ratio was developed to check the void ratio at stresses greater than $640 \mathrm{kPa}$. Using this relationship to extrapolate the void ratio at higher stresses resulted in a reduction of void ratio from the assumed 1.089 to 0.894 at the maximum pit level of RL $760 \mathrm{~m}$.

The void ratio was used to calculate the consolidated tailings volume, and the tailings solids level was interpolated from the pit storage curve. The model calculated the tailings solids level at each $1 \mathrm{~m}$ total increment up to RL $760 \mathrm{~m}$. External water inputs and outputs (groundwater inflow/outflow, evaporation, and runoff) were considered separately within the GoldSim model. The consolidation calculation was also performed for 24 hour time intervals as required for the GoldSim model over the first year of tailings deposition. The results of the calculations were then used to develop the inputs into the GoldSim model for the full modelling period.

\subsubsection{Decant}

Excess water will be decanted and recycled back to the processing plant. Different decanting rates were tested in the model and a rate of at least $40 \mathrm{~L} / \mathrm{s}$ was found to be required to keep the lake from overflowing during tailings deposition. The AWTP will be kept in commission in case it is needed to treat AMD impacted decant.

\subsubsection{Model results}

On the cessation of tailings deposition the water level is predicted to be approximately $70 \mathrm{~m}$ above the tailings surface. However, the lake will slowly dissipate due to evaporation and lack of groundwater contributions, a $20 \mathrm{~m}$ deep lake is predicted to persist after 200 years (Figure 6). In the longer term, evaporation exceeds rainfall and the lake is expected to become ephemeral given that groundwater inflow won't be sustained in the long-term. The lake volume will vary seasonally and annually, due to variations in rainfall and evaporation. The tailings solids are predicted to cover approximately $85 \%$ of the hot black shale (Figure 6). Outputs from the water balance, comprising a time series of monthly volumes of each water balance component were the inputs to the geochemical modelling.

\subsection{Geochemical model}

A thermodynamic based geochemical model was developed to assist in the prediction of water quality in the pit during deposition and post-closure. The model was constructed using the U.S. Geological Survey modelling software PHREEQC (Parkhurst \& Appelo 1999) and a variation of the minteq version 4 dataset. PHREEQC is industry standard software for carrying out low temperature aqueous geochemical calculations. The database minteq.v4.dat was used to define thermodynamic data for aqueous species, and gas and mineral phases. PHREEQC has been used to establish the speciation and saturation of aquatic species and predict geochemical changes resulting from the proposed disposal of tailings within the pit. 
The geochemical model predicted the evolution of water quality in the pit as contributions from incident rainfall, runoff from exposed pit wall geological units, groundwater and tailings mix over time. The relative contributions of each input, and subsequent change in pit water and solids levels, and volumes were calculated by GoldSim.

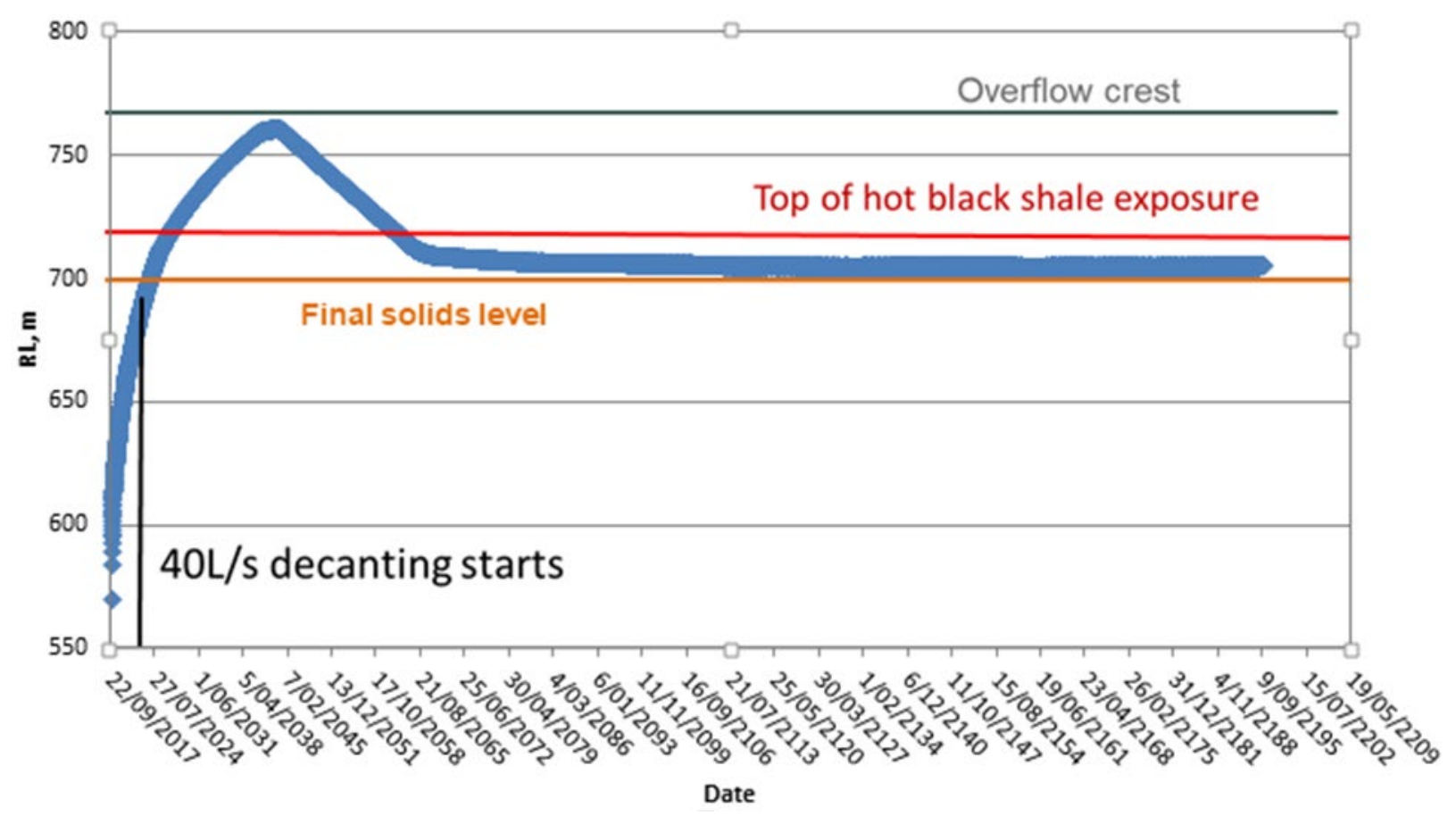

Figure 6 Pit lake water level as predicted by the water and solids balance modelling

The model included the mixing, precipitation and evaporation reactions that will occur as tailings inflow mixes with groundwater inflows, runoff and the pit lake that forms upon consolidation of tailings solids. While it is expected that some minerals formed within the lake or deposited in the lake via tailings inflow will dissolve over time to provide some degree of buffering within the pit lake, dissolution reactions from solids were not included in the geochemical model. The reason for excluding mineral dissolution reactions from the model is that this process will most likely occur within the porewater of settled tailings and precipitated minerals flocculated with the tailings. Thus, their availability to provide buffering will be controlled by the upward movement of porewaters into the pit lake, which will likely be a much longer term process. Sorption was excluded from the model in order to be conservative. All reactions were assumed to occur in an open system. Evaporation was included in the model as a negative mixing ratio. Decant from the pit, as predicted by the GoldSim model, was negligible and therefore was not included in the PHREEQC modelling.

The following assumptions were made:

- Laboratory testing data were representative of source terms.

- All reactions reach equilibrium instantaneously.

- The system is open with respect to $\mathrm{CO}_{2}$ and $\mathrm{O}_{2}$.

\subsubsection{Source terms}

A comprehensive leach test and kinetic column test database from the mine area was used to derive the source terms for the system. Given the reactivity of the MCS, which displays no lag period for the onset of oxidation, available column and leach data were deemed appropriate to represent field conditions. Source terms were conservatively assumed to be at steady state for the duration of the modelling (i.e. pit wall rock continuously reacts at rates observed in laboratory studies for the duration of the modelling period and 
solutes released during oxidation reach the system via contact with pit wall runoff). Source terms for pit wall runoff were split proportionately to each geological unit exposed on the pit wall above the predicted pit water level for each time step, and the corresponding cumulative areas of each geological unit for the corresponding bench as estimated by Vulcan modelling. Regular monitoring data from the thickener and the existing tailings storage facility were used to represent incoming tailings. Solutes present at concentrations below the laboratory detection limit were assumed to be present at the detection limit. Concentrations of sulphate were set to adjust to achieve charge balance.

Solids composition of tailings was not included in the model, only phases that reached equilibrium during mixing and evaporation. The equilibrium phases included in the model were selected based on secondary minerals theoretically known to precipitate in mine waters, in addition to site specific mineralogical data collected within the pit. However, most minerals identified in the field have not been included in the minteq.v4.dat database and hence were not able to be included in the model. Secondary minerals were allowed to precipitate if saturation was reached.

\subsubsection{Model results}

The results of the geochemical modelling indicated that the pit lake above the tailings solids will be slightly alkaline $(\mathrm{pH}$ 8.1) during the deposition of tailings, with alkalinity slowly dissipating post-deposition as the result of ongoing alkalinity consumption by AMD contributions from remaining PAF exposures on the pit wall, which are assumed to continuously generate acidity within the modelling period. Given the initial alkalinity considered in the tailings, the lake remained circum-neutral $(\mathrm{pH} \mathrm{6})$ for the duration of the modelling period (i.e. 200 years) as shown in Figure 7. Sulphate and conservative anion concentrations were predicted to increase in time driven by the continuous evaporation occurring in the lake (Figure 8), while most metal concentrations were predicted to be low to negligible given that the $\mathrm{pH}$ remained circumneutral during the modelling period. Further work for this project is well underway and will consider longer modelling periods (i.e. up to 1,000 years) and engineering management options, should unacceptable environmental outcomes be predicted to occur during the post-closure period.

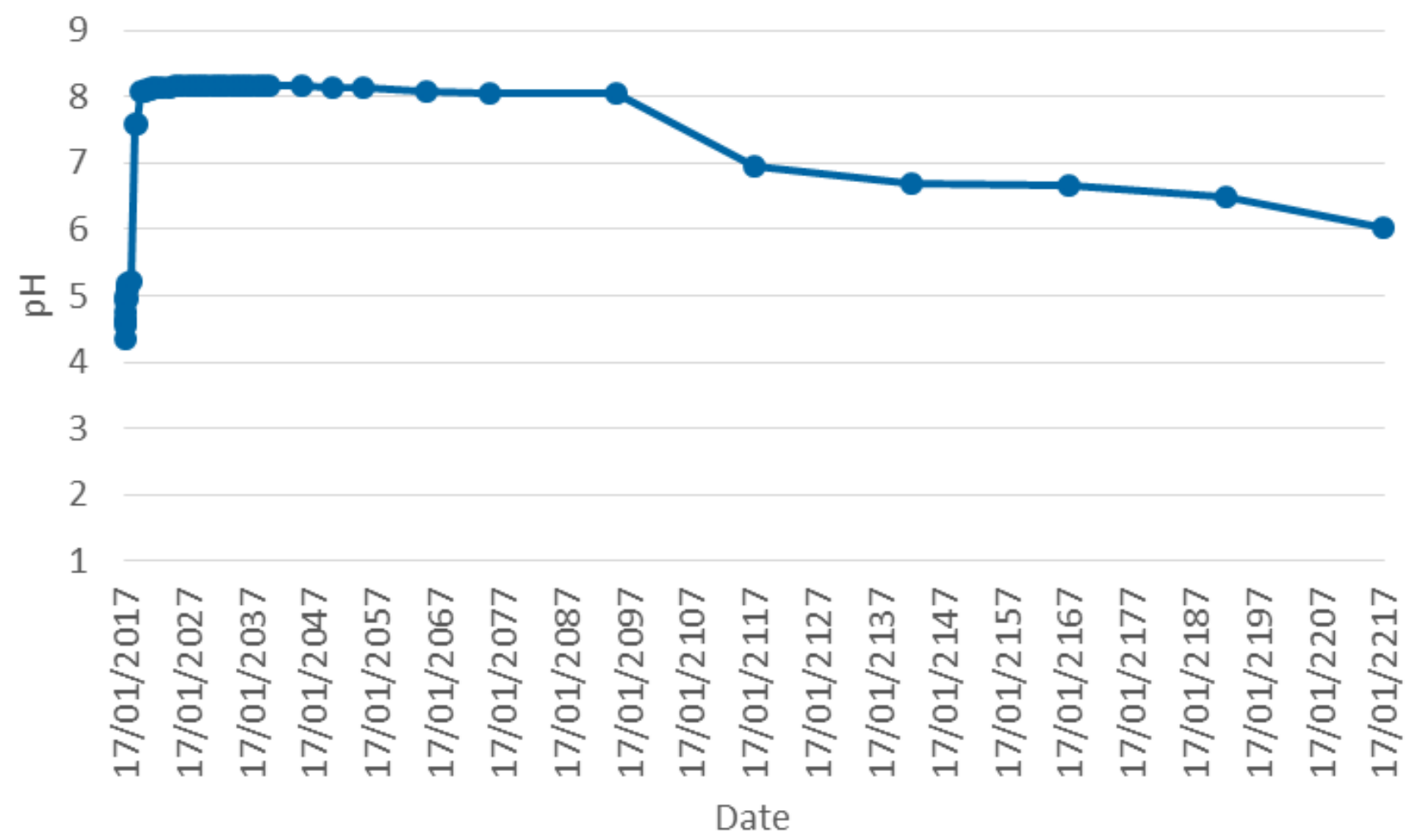

Figure $7 \quad$ Modelled $\mathrm{pH}$ of the pit lake water over 200 years 


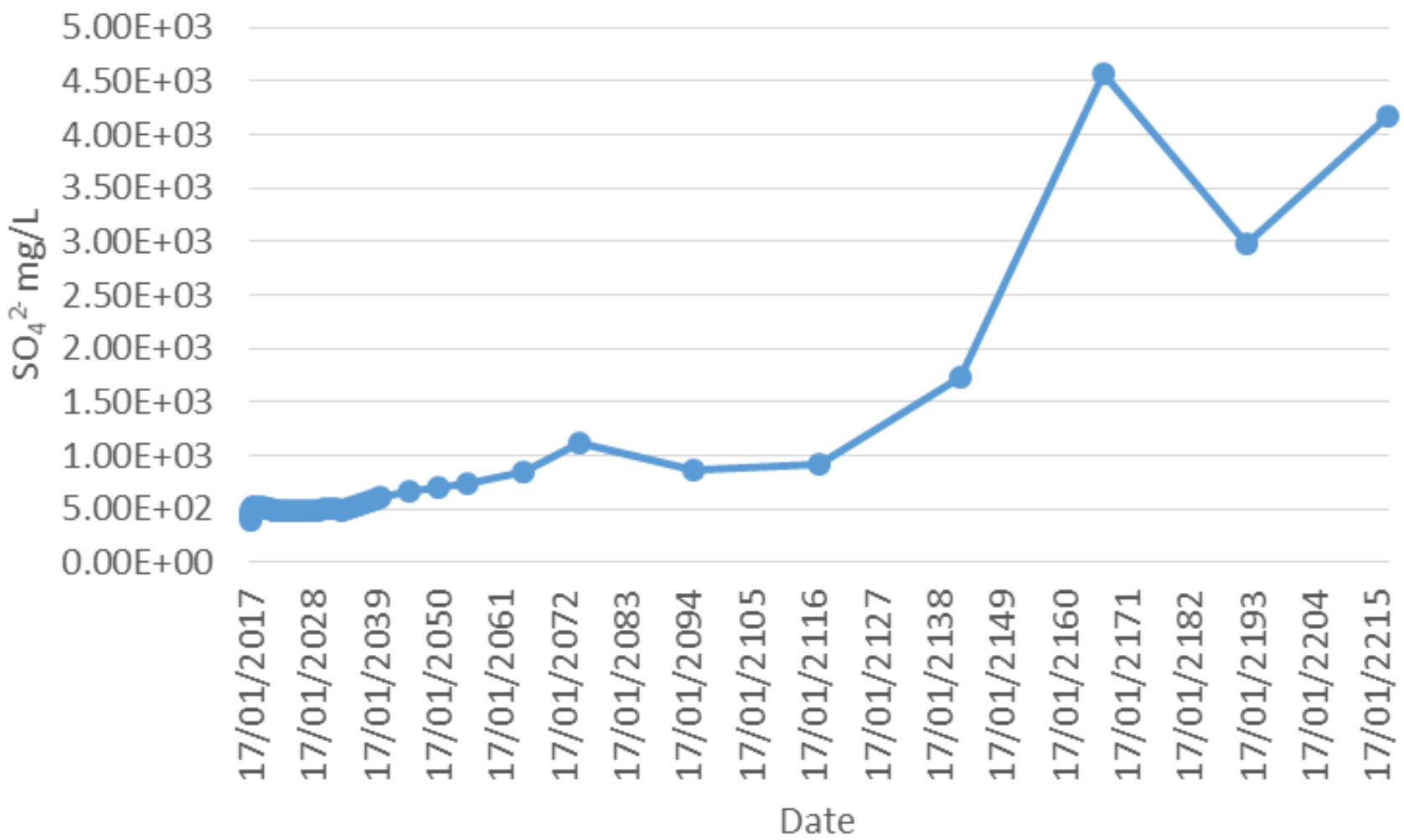

Figure 8 Modelled sulphate concentration in the pit lake water over 200 years

\section{$4 \quad$ Closure outcomes}

Modelling has predicted a gradual recession in pit lake depths on the cessation of tailings deposition. A $20 \mathrm{~m}$ deep lake persists after 200 years, in the longer term, evaporation exceeds rainfall and the lake is expected to become ephemeral. The lake volume will vary seasonally and annually, due to variations in rainfall and evaporation. It is predicted that tailings will cover $85 \%$ of the hot MCS on the pit floor and walls; while the remaining $15 \%$ of the hot MCS will not lower the $\mathrm{pH}$ of the pond below circum-neutral levels during the 200-year period used in the model. The deposited tailings cover is expected to provide both a geochemical buffer and a physical low permeability barrier above the pit floor that will prevent groundwater ingress and oxidation of most of the hot MCS exposed on the pit.

The results of the geochemical modelling indicated that the lake remained circum-neutral for the duration of the modelling period (i.e. 200 years). Sulphate and conservative anion concentrations were predicted to increase in time driven by the continuous evaporation occurring in the lake, while most metal concentrations were predicted to be low to negligible assuming $\mathrm{pH}$ remained circum-neutral. Modelling that considers a longer time period (i.e. up to 1,000 years) is underway to predict conditions within the ephemeral pit lake post-closure. The outcomes of this work will be used to determine if further management is required to ensure an acceptable closure outcome.

Groundwater inflow is expected to decrease significantly during the initial years of tailings deposition, while outflow is not expected during deposition. Both, inflow and outflow are predicted to be negligible at closure due to limited hydraulic continuity between the pit and the surrounding aquifer. A preliminary source, pathway, receptor assessment has been completed and concluded there were no surface water pathways, and limited groundwater pathways due to the limited hydraulic continuity with surrounding groundwater aquifers.

Backfilling the pit void with tailings has several benefits including reducing the pit lake volume and improving pit water quality. The preferred closure strategy has the additional benefit of reducing ex-pit tailings storage requirements and the associated environmental impacts and construction costs. 
Operational costs are also predicted to be less for the in-pit tailings facility. Thus, tailings deposition into the pit has been identified as the most cost-effective solution for future tailings capacity requirements.

\section{Conclusion}

In conclusion depositing tailings into this pit is expected to improve environmental closure outcomes, and reduce operating and closure implementation costs. The next stage of works is well underway and is focusing on: refining the pit lake modelling, including extending the model period to 1,000 years; exploring opportunities to further improve the closure outcome; and developing a detailed engineering design for the in-pit tailings facility. Regulatory approval of the in-pit tailings facility is required, and consultation has commenced.

\section{Acknowledgement}

GHD's and Klohn Crippen Berger Ltd's contribution to the modelling, and the assistance of the Rio Tinto team with technical information and project management, is gratefully acknowledged.

\section{References}

Australian and New Zealand Environment and Conservation Council \& Agriculture and Resource Management Council of Australia and New Zealand 2000, Australian and New Zealand Guidelines for Fresh and Marine Water Quality, https://www.waterquality.gov.au/anz-guidelines/resources/previous-guidelines/anzecc-armcanz-2000

Department of Industry, Tourism and Resources 2016, Preventing Acid and Metalliferous Drainage, Leading Practice Sustainable Development Program for the Mining Industry, Canberra.

Green, R 2009, 'Holistic management of sulphides at Rio Tinto Iron Ore's Pilbara mine sites', Transactions of the Institutions of Mining and Metallurgy: Section A: Mining Technology, vol. 118, issue 3-4, pp. 232-237.

Hill, RD 1968, Mine Drainage Treatment: State of the art and research needs, Federal Water Pollution Control Administration, US Department of Interior, Cincinnati.

Johnson, S \& Wright, A 2003, Mine void water resource issues in Western Australia, Western Australia, Water and Rivers Commission, Report HG 9, Hydrogeological Record Series, Perth.

Kossick, R \& Miller, I 2017, GoldSim User's Manual, GoldSim Technology Group LLC, Issaquah.

Luke, G, Burke, K \& O’Brien, T 1987, Evaporation data for Western Australia, Resource Management Technical Report No. 65, Department of Agriculture and Food, Perth.

McMahon, T, Peel, M, Lowe, L, Srikanthan, R \& McVicar, T 2013, 'Estimating actual, potential, reference crop and pan evaporation using standard meteorological data: a pragmatic synthesis', Hydrology and Earth System Sciences, no. 17, pp. 1331-1363.

Parkhurst, D \& Appelo, C 1999, User's guide to PHREEQC version 3 - a computer program for speciation, batch-reaction, onedimensional transport, and inverse geochemical calculations, US Geological Survey, Reston.

Thorne, W, Hagemann, S \& Barley, M 2004, 'Petrographic and geochemical evidence for hydrothermal evolution of the North Deposit, Mt Tom Price, Western Australia', Mineralium Deposita, vol. 39, pp. 766-783.

Vardavas, I \& Fountoulakis, A 1996, 'Estimation of lake evaporation from standard meteorological measurements: application to four Australian lakes in different climatic regions', Ecological Modelling, vol. 84, no. 1-3, pp. 139-150. 